\title{
Synthesis of Novel Xanthone Analogues and Their Growth Inhibitory Activity Against Human Lung Cancer A549 Cells
}

This article was published in the following Dove Press journal: Drug Design, Development and Therapy

Junqi Wu, ${ }^{1,2, *}$ Jinwei Dai, ${ }^{1,3, *}$ Yuyang Zhang, (D) 1,3 Jing Wang,' Lei Huang,' Hongmei Ding,' Tiejun Li, ${ }^{1,4}$ Yuefan Zhang, ${ }^{1,5}$ Junqin Mao, 6 Shichong Yu'

'College of Pharmacy, Naval Medical University, Shanghai 200433, People's Republic of China; ${ }^{2}$ Department of Thoracic Surgery, Shanghai Pulmonary Hospital, Tongji University School of Medicine, Shanghai 200433, People's Republic of China; ${ }^{3}$ Department of Pharmacology, School of Life Science and Biopharmaceutics, Shenyang Pharmaceutical University, Shenyang I I00 16, People's Republic of China; ${ }^{4}$ Department of Pharmacy, Punan Hospital, Shanghai 200I25, People's Republic of China; ${ }^{5}$ Biomedical Innovation R\&D Center, School of Medicine, Shanghai University, Shanghai, 20444, People's Republic of China; ${ }^{6}$ Department of Pharmacy, Shanghai Pudong New Area People's Hospital, Shanghai 201299, People's Republic of China

*These authors contributed equally to this work
Purpose: Xanthones demonstrated an array of pharmacological activities via non-covalent DNA interaction and have been widely utilized in new drug research. The introduction of the polar 1,2,3-triazole ring located at the C3-position of xanthone has not been reported thus far. Methods: In the present study, a series of xanthone derivatives were designed, synthesized, and characterized through ${ }^{1} \mathrm{H}$ NMR, ${ }^{13} \mathrm{C} \mathrm{NMR}$, and MS. The methyl thiazolyl tetrazolium method was used to evaluate the cytotoxic activity of compounds. Furthermore, the structureactivity relationship and the potential mechanism of target compounds were investigated.

Results: The $\mathrm{IC}_{50}$ showed that the inhibitory activity of 18 target compounds was higher than that of the original xanthone intermediate 4 . In particular, compound $1 \mathrm{j}$ was the most active agent against $\mathrm{A} 549$ cancer cells $\left(\mathrm{IC}_{50}=32.4 \pm 2.2 \mu \mathrm{M}\right)$. Moreover, apoptosis analysis indicated different contributions of early/late apoptosis to cell death for compounds $1 \mathrm{~h}$ and $1 \mathrm{j}$. The results of Western blotting analysis showed that compound $1 \mathrm{j}$ significantly increased the expression of caspase 3, Bax, and c-Jun N-terminal kinase, and regulated p53 to a better healthy state in cancer cells.

Conclusion: We synthesized several derivatives of xanthone and evaluated their cytotoxicity. The evidence suggested that compound $1 \mathrm{j}$ possessed greater anticancer potential for further evaluations.

Keywords: synthesis, xanthone, derivatives, lung cancer cell, apoptosis

\section{Introduction}

Lung cancer is currently the most common type of cancer affecting both men and women, owing to the high prevalence of smoking worldwide. ${ }^{1,2}$ According to the American Cancer Society, lung cancer was the leading cause of cancer-related mortality in 2016 in the United States of America, with estimated 158,080 deaths $(\sim 27 \%){ }^{3}$ Conventional treatments against cancer, such as surgery and radiation therapy, are not feasible in advanced lung cancer mainly owing to the location of the cancer cells in the body. ${ }^{4}$ Chemotherapy is an effective systemic treatment option; chemotherapeutic drugs can disrupt the cell cycle/division and angiogenesis or induce apoptosis of cancer cells through several signaling pathways. ${ }^{5}$ Nevertheless, owing to the high rate of cancer-related mortality, development of resistance, and occurrence of serious adverse effects, continuous efforts are exerted by scientists to develop new drugs for the treatment of cancer. ${ }^{6}$

Xanthones are bioactive substances isolated and extracted from plants and microorganisms. ${ }^{7}$ Their basic skeleton had been confirmed as a biphenyl pyranone
Correspondence: Junqin Mao

Email maojq204@163.com

Shichong Yu

$\mathrm{Tel} / \mathrm{Fax}+86-21-8 \mid 87 / 228$

Email yuscc1008@I63.com 
with a planar three-ring structure (Figure 1A). Notably, the derivatives of xanthone possess an array of pharmacological activities (e.g., antitumor, antibacterial, antioxidant, hypolipidemic, etc.). ${ }^{8,9}$ Based on their planar structure, they act as efficient DNA intercalators and show anticancer activity via non-covalent DNA interaction. ${ }^{10}$ Previous studies have reported structures of natural xanthones, such as 5,6-dimethylxanthone-4-acetic acid (DMXAA; $\mathrm{IC}_{50}=48.4$ $\mu \mathrm{M}$ for MDA-MB-231 cells) (Figure 1) and globosuxanthone $\mathrm{A}$, which showed outstanding anti-proliferative activity. ${ }^{11,12}$ In particular, DMXAA can interact with various biological targets via diverse actions. DMXAA is currently entering the phase III clinical trial stage; consequently, the synthesis of xanthone derivatives with excellent anticancer activity has attracted considerable attention. A series of xanthone analogues were reported and demonstrated improved in vitro antitumor activity versus the parent xanthone and drug-like properties. ${ }^{13,14}$ For example, a caged xanthone (Figure $1 \mathrm{~B} ; \mathrm{IC}_{50}=3.60 \mu \mathrm{M}$ for $\mathrm{A} 549$ cells) was synthesized using the prenyl moiety of its parent xanthone, ${ }^{15,16}$ while 3-phenylxanthone (Figure $1 \mathrm{C} ; \mathrm{IC}_{50}=$ $6.27 \mu \mathrm{M}$ for QGY-7703 cells) was identified as a potent and promising antitumor agent. ${ }^{17}$

In the side chain, 1,2,3-triazole could serve as a privileged building block for the synthesis of bioconjugates owing to its high stability, selectivity, and fewer adverse reactions. ${ }^{18}$ It exhibited formidable stability under basic and acid hydrolysis, including oxidative and reductive reactions. Moreover, this heterocycle was the bioisostere of amide and interacted with biomolecular targets through hydrogen-bonding. ${ }^{19}$ This attractive chromophore showed diverse activities (e.g., antibacterial, antiallergic, antiviral, antimalarial, antifungal, and anticancer). ${ }^{20-24}$ In addition, it interacted with DNA and acted as a supporting motif for

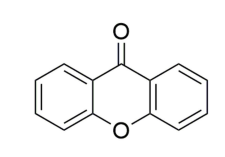

A

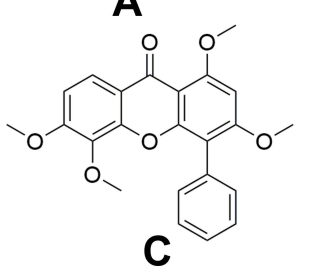

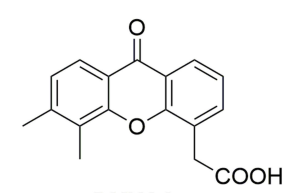

DMXAA

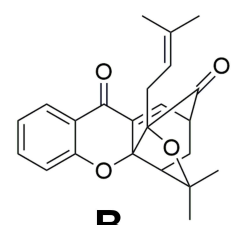

B

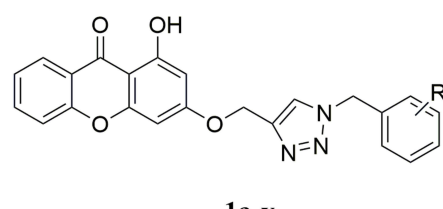

1a-v
Figure I Chemical structures of xanthones (A) Basic structure of xanthone, (B, C) Derivatives of xanthone.
DNA targeting compounds, such as xanthones. ${ }^{25,26} \mathrm{Cu}(\mathrm{I})$ catalyzed azide-alkyne cycloaddition (Click Reaction) rapidly yields bioactive molecules linked through 1,2,3-triazole with high atom economy, and have been widely applied to combinatorial synthesis and bio-conjugate chemistry. ${ }^{27}$

However, to the best of our knowledge, the incorporation of the polar 1,2,3-triazole ring located at the $\mathrm{C} 3$-position of xanthone has not been reported in prior studies. Therefore, 22 heterocyclic xanthone derivatives were designed and synthesized to explore the antiproliferative effect associated with the 1,2,3-triazole and substituent benzyls of the xanthone framework (1a-v, Figure 1). The antiproliferative effects of all derivatives were evaluated in vitro using the MTT colorimetric method against human lung cancer cell line A549. ${ }^{28,29}$ Furthermore, we carefully selected potential compounds to examine the main mechanism involved in cancer cell death.

\section{Materials and Methods}

\section{Chemistry}

Target compounds $1 \mathrm{a}-\mathrm{v}$ were synthesized on the basis of a reasonable synthetic route strategy (Scheme 1). In this method, synthesis of compound 4 was achieved by applying Eaton's reagents starting from 2-hydroxybenzoic acid 2 and 1, 3, 5-trihydroxybenzene 3. Compound 5 was synthesized through the $O$-alkylation reaction, in the presence of $\mathrm{K}_{2} \mathrm{CO}_{3}, \mathrm{KI}$, and propargyl bromide in acetonitrile at room temperature. The target compounds $1 \mathrm{a}-\mathrm{v}$ were obtained by performing a click reaction with variously substituted benzyl azides. All compounds were
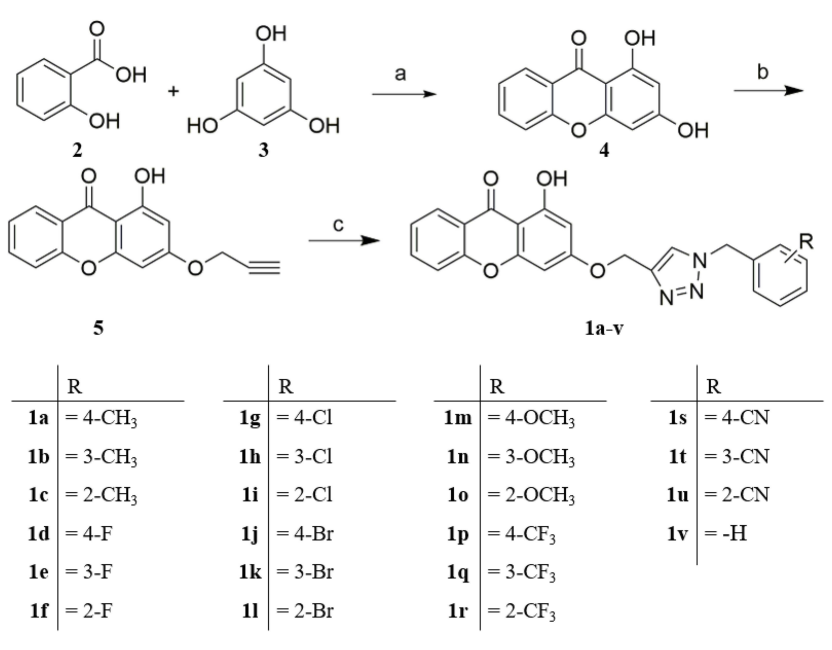

Scheme I Synthesis of compounds Ia-v. Reagents and conditions: (A) $\mathrm{P}_{2} \mathrm{O}_{5} / \mathrm{CH}_{3}$ $\mathrm{SO}_{3} \mathrm{H}, 85^{\circ} \mathrm{C}, 2.5 \mathrm{~h}$; (B) Propargyl bromide, $\mathrm{K}_{2} \mathrm{CO}_{3}, \mathrm{KI}$, acetonitrile, $6 \mathrm{~h}$; (C) Corresponding benzyl azide, DMSO, $\mathrm{CuSO}_{4} \cdot 5 \mathrm{H}_{2} \mathrm{O}$, Vit- Na, r.t., 2 h. 
characterized through ${ }^{1} \mathrm{H}$ NMR, ${ }^{13} \mathrm{C}$ NMR, and MS. The details are provided in the Supplementary Information of this article.

\section{Biological Assays}

We used the methyl thiazolyl tetrazolium (MTT) method to measure the cytotoxic activity of the target compounds against human lung cancer A549 cells. The results of this experiment are summarized in Table $1 .^{28,29}$ The A549 cells were obtained from the Cell Bank of the Chinese Academy of Sciences (Shanghai, China). Cells were seeded at a density of $5 \times 10^{4}$ cells $/ \mathrm{mL}$, and the compounds were added to the supernatant at different concentrations (i.e., $50 \mu \mathrm{g} / \mathrm{mL}$, $30 \mu \mathrm{g} / \mathrm{mL}, 10 \mu \mathrm{g} / \mathrm{mL}, 2 \mu \mathrm{g} / \mathrm{mL}, 0.4 \mu \mathrm{g} / \mathrm{mL}$ ). Cells not treated with compounds served as negative control, while those treated with pirarubicin hydrochloride served as positive control. Twelve hours later, MTT $(20 \mu \mathrm{L}, 5 \mathrm{mg} / \mathrm{mL})$ was added to the cells, and the cells were incubated at $37^{\circ} \mathrm{C}$ for $4 \mathrm{~h}$ in the dark. Subsequently, dimethyl sulfoxide was added and the mixture was incubated for $10 \mathrm{~min}$. All compounds

Table I Anticancer Activities of the Target Compounds in vitro $\left(\mathrm{IC}_{50}, \mu \mathrm{M}\right)$

\begin{tabular}{|c|c|c|}
\hline Compounds & $\mathbf{R}$ & $I_{50}(\mu M)$ A549 \\
\hline la & $4-\mathrm{CH}_{3}$ & $113.8 \pm 6.2$ \\
\hline $\mathrm{lb}$ & $3-\mathrm{CH}_{3}$ & $92.5 \pm 3.9$ \\
\hline Ic & $2-\mathrm{CH}_{3}$ & $67.3 \pm 3.3$ \\
\hline Id & $4-\mathrm{F}$ & $102.3 \pm 4.1$ \\
\hline le & $3-F$ & $292.4 \pm 6.0$ \\
\hline If & $2-\mathrm{F}$ & $96.8 \pm 5.5$ \\
\hline $\lg$ & $4-\mathrm{Cl}$ & $51.5 \pm 2.6$ \\
\hline Ih & $3-\mathrm{Cl}$ & $40.2 \pm 3.8$ \\
\hline $\mathrm{li}$ & $2-\mathrm{Cl}$ & $596.6 \pm 9.8$ \\
\hline $\mathrm{lj}$ & $4-\mathrm{Br}$ & $32.4 \pm 2.2$ \\
\hline Ik & $3-\mathrm{Br}$ & $71.5 \pm 6.3$ \\
\hline 11 & $2-\mathrm{Br}$ & $96.4 \pm 5.8$ \\
\hline $\mathrm{Im}$ & $4-\mathrm{OCH}_{3}$ & $264.1 \pm 6.2$ \\
\hline $\ln$ & $3-\mathrm{OCH}_{3}$ & $56.0 \pm 2.8$ \\
\hline lo & $2-\mathrm{OCH}_{3}$ & $104.8 \pm 4.7$ \\
\hline Ip & $4-\mathrm{CF}_{3}$ & $133.2 \pm 5.4$ \\
\hline $\mathrm{Iq}$ & $3-\mathrm{CF}_{3}$ & $74.2 \pm 4.3$ \\
\hline Ir & $2-\mathrm{CF}_{3}$ & $97.1 \pm 3.8$ \\
\hline Is & $4-\mathrm{CN}$ & $59.2 \pm 3.6$ \\
\hline $\mathrm{It}$ & $3-\mathrm{CN}$ & $76.4 \pm 5.4$ \\
\hline lu & $2-\mathrm{CN}$ & $97.7 \pm 3.4$ \\
\hline Iv & $\mathrm{H}$ & $133.2 \pm 4.2$ \\
\hline 4 & - & $340.7 \pm 4.8$ \\
\hline 5 & - & $268.4 \pm 3.5$ \\
\hline Pirarubicin Hydrochloride ${ }^{a}$ & - & $5.8 \pm 0.3$ \\
\hline
\end{tabular}

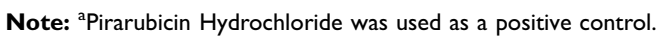

were incubated with A549 cells for $12 \mathrm{~h}$. The absorbance was measured at $490 \mathrm{~nm}$ using a microplate reader (Multiskan MK3, Thermo Scientific, USA). Cell survival in the control group was considered $100 \%$ and that of all other groups was normalized to this value. These procedures were performed in triplicate.

Western blotting was performed to separate the proteins. For the extraction of total protein, $5 \times 10^{5}$ A549 cells were lysed in Protein Extraction Regent (Pierce, Rockford, USA) supplemented with a protease inhibitor cocktail and centrifuged $(17,709 \mathrm{~g})$ for $15 \mathrm{~min}$ at $4^{\circ} \mathrm{C}$. Protein concentrations of the extracts were measured using the BCA assay (Pierce, Rockford, IL, USA) and equalized with the extraction reagent. Proteins were separated through sodium dodecyl sulfate-polyacrylamide gel electrophoresis and transferred to nitrocellulose membranes (Millipore, MA, USA). After the transfer, the proteins were immunoblotted with the corresponding primary antibody against caspase 3, p53, Bax, and c-Jun N-terminal kinase (JNK) (Cell Signaling Technology, Danvers, MA, USA) (dilution ratio: 1:5000). The blots were incubated with the corresponding horseradish peroxidase-conjugated secondary antibody (Kangchen, Shanghai, China) for $1 \mathrm{~h}$ at room temperature (dilution ratio: 1:5000). The intensity of each protein band was measured using Quantity One.

A549 cells $\left(1 \times 10^{5}\right.$ cells $\left./ \mathrm{mL}\right)$ were seeded in six-well plates and treated with either vehicle or the indicated concentrations of $1 \mathrm{j}$ and $1 \mathrm{~h}$ for $48 \mathrm{hr}$. The cells were collected through centrifugation at $4{ }^{\circ} \mathrm{C}$ and washed twice with ice-cold phosphate-buffered saline. Subsequently, the cells were stained with Annexin-V-FITC/PI (KeyGEN; Nanjing, China) and analyzed via flow cytometry (BD FACS Calibur, Franklin Lakes, CA, USA).

\section{Statistical Analysis}

Data are presented as means \pm standard deviation. One-way analysis of variance was used to calculate statistical differences. All statistical analyses in this study were conducted using SPSS for Windows, version 22.0 (IBM, Armonk, NY, USA). A $p<0.05$ denoted statistical significance.

\section{Results and Discussion}

As shown in Table 1, 22 target compounds were synthesized after the introduction of 1,2,3-triazole and the heterocycle group. Of those, 18 compounds showed higher activity compared with intermediate $4\left(\mathrm{IC}_{50}=340.7 \pm 4.8 \mu \mathrm{M}\right)$ and 5 $\left(\mathrm{IC}_{50}=268.4 \pm 3.5 \mu \mathrm{M}\right)$. The extensional structure of various substituted groups resulted in a significantly 
A

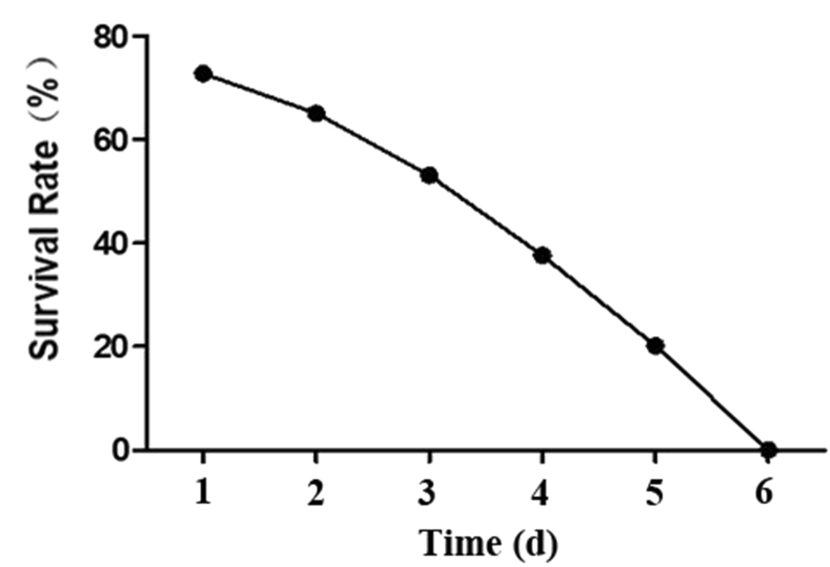

B

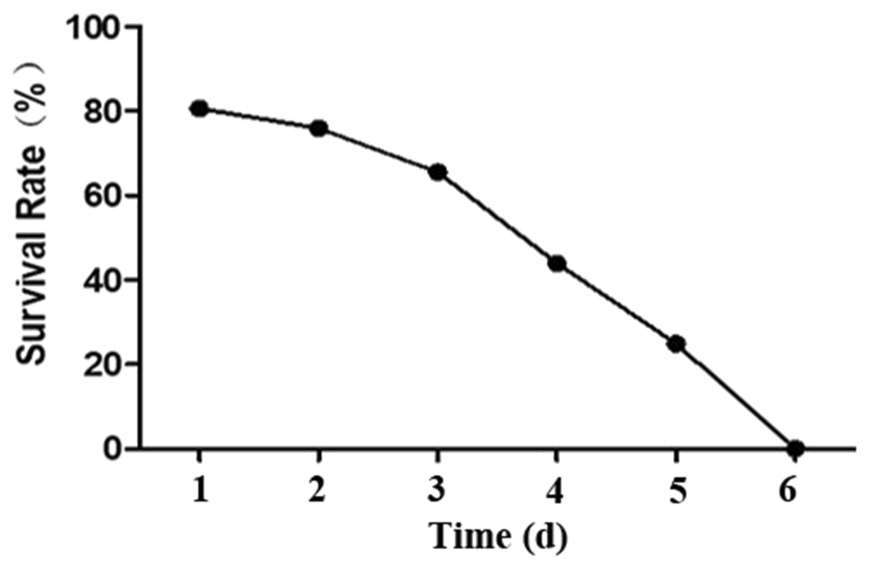

Figure 2 Ih $(\mathbf{A})$ (concentration: $46 \mu \mathrm{M}$ ) and Ij (B) (concentration: $46 \mu \mathrm{M}$ ) induced cell death in human umbilical vein endothelial cells in vitro.

increased anticancer effect versus compound $1 \mathrm{v}$ with the benzyl group $\left(\mathrm{IC}_{50}=133.2 \pm 4.2 \mu \mathrm{M}\right)$. In detail, the compounds with substituted deactivating groups $(1 \mathrm{~d}-\mathrm{k}, 1 \mathrm{p}-\mathrm{u})$ possessed higher activity versus those with electrondonating groups $(1 \mathrm{a}-\mathrm{c}, 1 \mathrm{~m}-\mathrm{o})$. Of note, the compounds with weak electron-withdrawing groups $(1 \mathrm{~g}, 1 \mathrm{~h}, 1 \mathrm{j}, 1 \mathrm{k})$

\section{A}

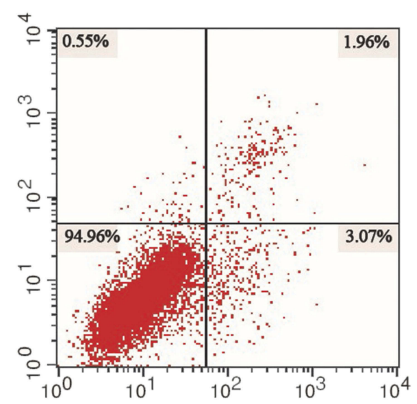

Con

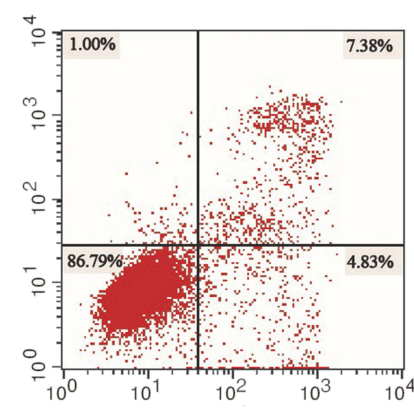

23

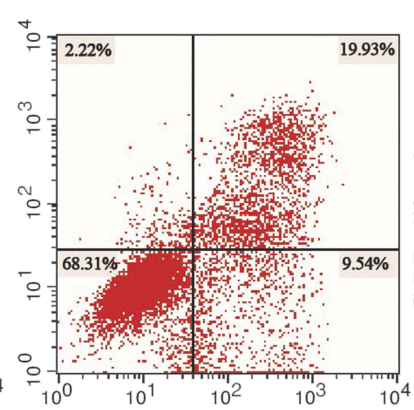

$46 \mu \mathrm{M}$

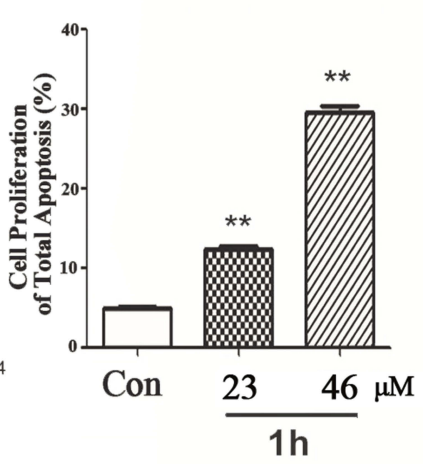

B

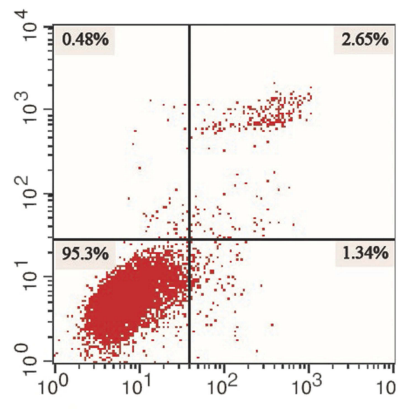

Con

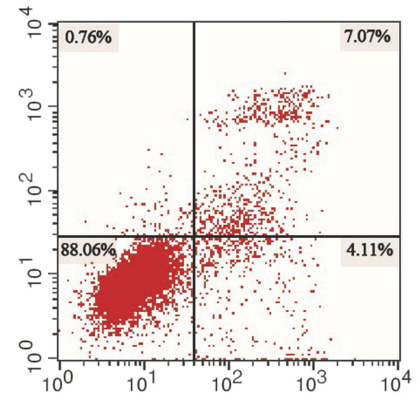

17

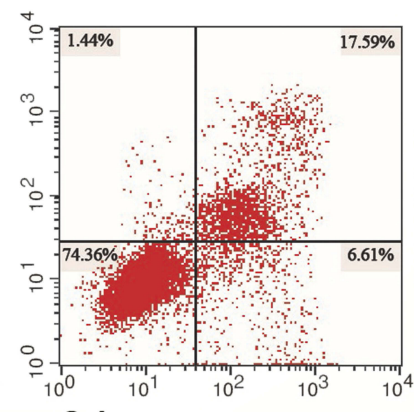

$34 \mu \mathrm{M}$

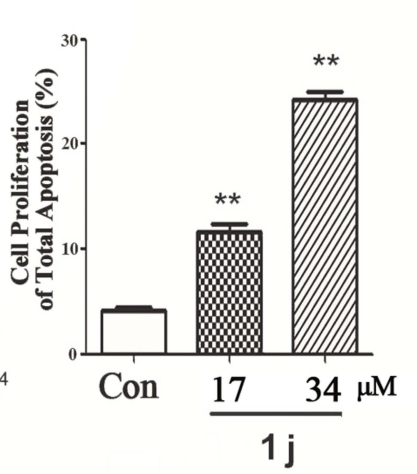

Figure $3 \mathbf{~ I h}$ and $\mathbf{I j}$ induced apoptosis in cancer A549 cells. Representative scatter diagrams. The A549 cells were pre-treated with (A) Ih at a dose of 0,23 , and $46 \mu \mathrm{M}$ ( 0 , I0, and $20 \mu \mathrm{g} / \mathrm{mL}),(B) \mathrm{lj}$ at a dose of 0,17 , and $34 \mu \mathrm{M}(0,8$ and $16 \mu \mathrm{g} / \mathrm{mL})$, respectively, for $48 \mathrm{~h}$. Apoptotic cells were stained with Annexin V-FITC and PI, and measured using flow cytometry. ${ }^{* *} \mathrm{p}<0.01$ vs Con. 
demonstrated the highest activity in this series. Among compounds with substituted halogen, the compound with replaced para bromide exhibited the highest anticancer activity $\left(\mathrm{IC}_{50}=32.4 \pm 2.2 \mu \mathrm{M}\right)$. However, the $\mathrm{IC}_{50}$ values of compounds $1 \mathrm{a}-\mathrm{v}$ were lower than that of pirarubicin hydrochloride, an effective anticancer drug used in clinical practice. Two representative compounds, namely $1 \mathrm{~h}\left(\mathrm{IC}_{50}=40.2\right.$ $\pm 3.8 \mu \mathrm{M})$ and $1 \mathrm{j}\left(\mathrm{IC}_{50}=32.4 \pm 2.2 \mu \mathrm{M}\right)$, presented strong activity against lung cancer A549 cells. In addition, these compounds obviously decreased the survival rate of human umbilical vein endothelial cells, and resulted in toxic effects on normal cells at concentrations of $46 \mu \mathrm{M}$ and $34 \mu \mathrm{M}$, respectively (Figure 2).

Owing to their higher activity against cancer cells, compounds $1 \mathrm{~h}$ (low dose: $10 \mu \mathrm{g} / \mathrm{mL}, 23 \mu \mathrm{M}$, high dose:
$20 \mu \mathrm{g} / \mathrm{mL}, 46 \mu \mathrm{M}$ ) and $1 \mathrm{j}$ (low dose: $8 \mu \mathrm{g} / \mathrm{mL}, 17 \mu \mathrm{M}$; high dose: $16 \mu \mathrm{g} / \mathrm{mL}, 34 \mu \mathrm{M}$ ) were selected for further evaluation. Firstly, their effect of these compounds on apoptosis was investigated. Two doses (low dose, high dose) were used in the experiment and the results are presented in Figure 3. At the low dose, the rate of total apoptosis induced by $1 \mathrm{~h}$ and $1 \mathrm{j}$ was only $12.21 \%$ and $11.18 \%$, respectively. Notably, at the high dose, $1 \mathrm{j}$ resulted in $24.20 \%$ and $17.59 \%$ total and later apoptosis, respectively. The effect of $1 \mathrm{~h}$ on later apoptosis also markedly contributed to cell death (19.93\%). There was no significant difference between the low and high dose groups in terms of early apoptosis. Furthermore, A549 cells were incubated with $1 \mathrm{~h}(46 \mu \mathrm{M})$ and $1 \mathrm{j}(34 \mu \mathrm{M})$ for $72 \mathrm{~h}$. The rate of total apoptosis increased with time (Figure 4).
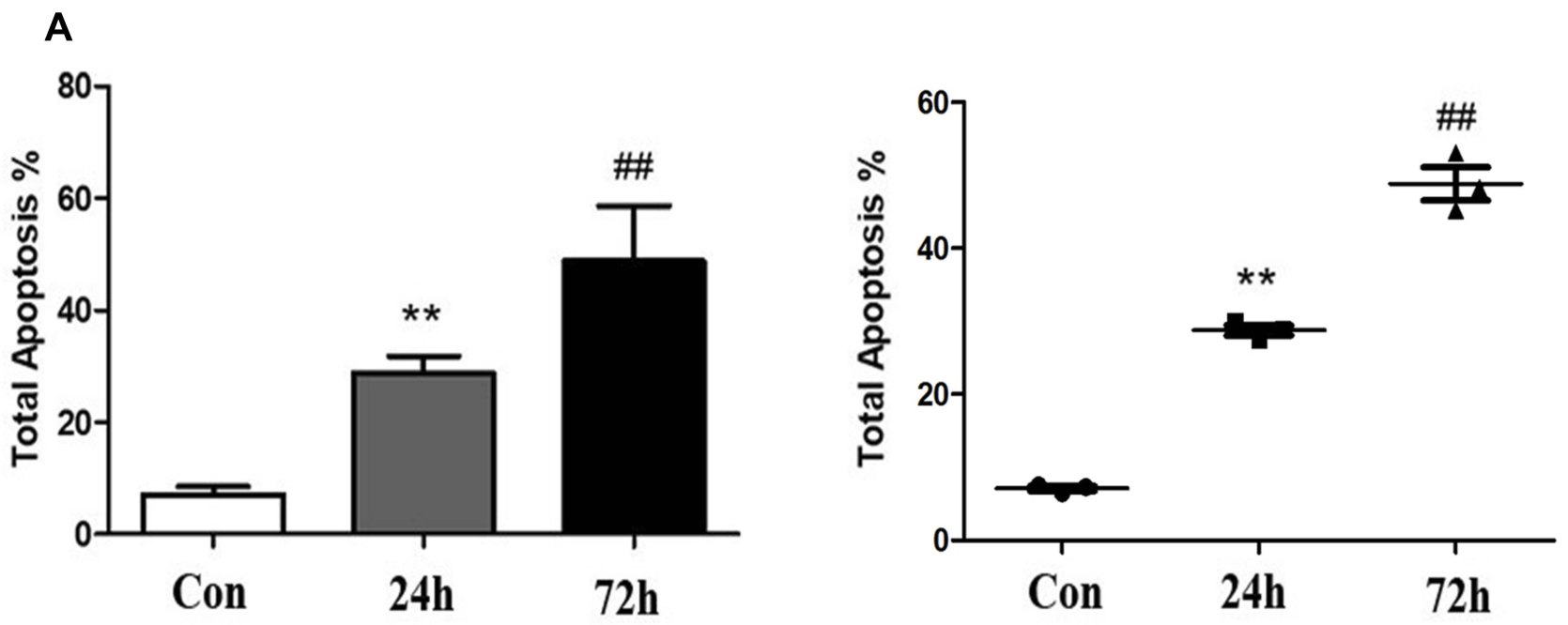

B
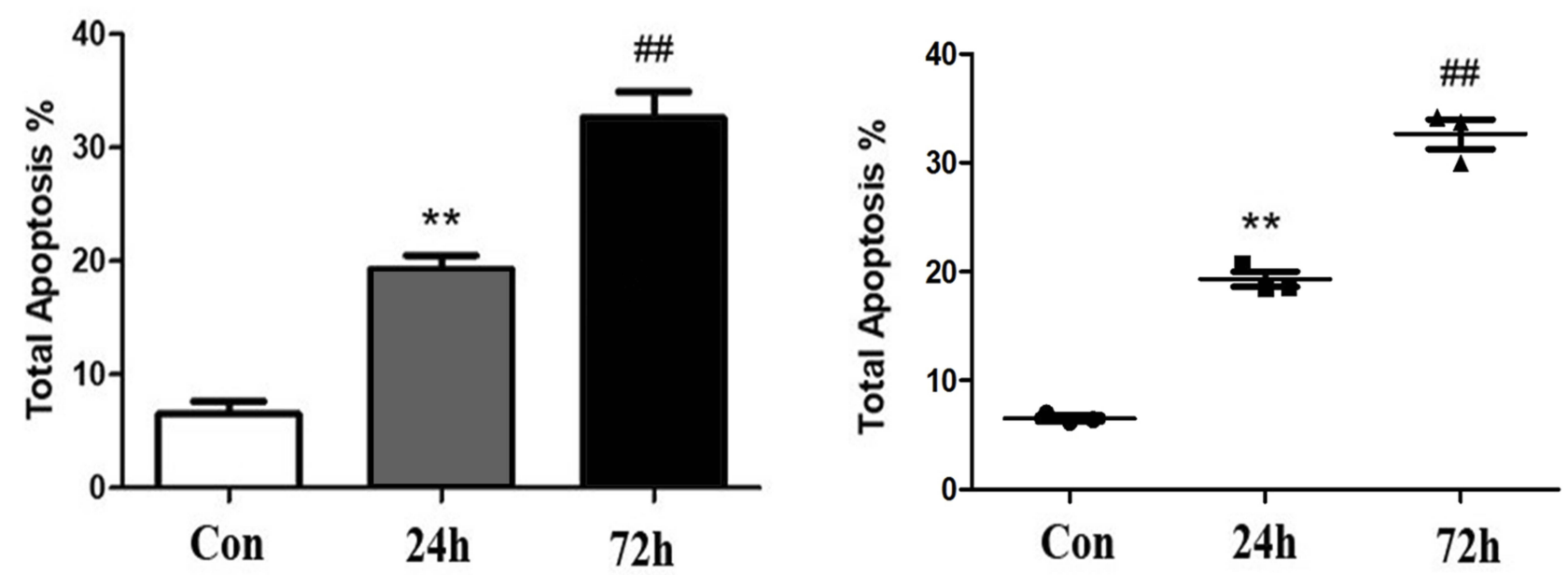

Figure $4 \mathrm{Ih}$ and $\mathbf{l j}$ induced apoptosis in cancer A549 cells at 24 and $72 \mathrm{hrs} .{ }^{* *} \mathrm{p}<0.0 \mathrm{I}$ vs Con. $\mathrm{p}<0.0 \mathrm{l}$ vs $24 \mathrm{hrs}$. 
We used Western blotting to examine the expression of caspase 3, p53, Bax, and JNK in A549 cells after incubation with $1 \mathrm{~h}$ and $1 \mathrm{j}$ for $12 \mathrm{~h}$ to disclose the mechanism through which compounds $1 \mathrm{~h}$ and $1 \mathrm{j}$ prevented cancer cell growth. Caspase-3 was involved in the apoptotic process (i.e., chromatin condensation and DNA fragmentation). JNK played key roles in regulating cell proliferation, apoptosis, and differentiation. As shown in Figure 5, we found that both compounds $1 \mathrm{j}$ and $1 \mathrm{~h}$ increased the expression of caspase-3 and JNK in A549 cells. Interestingly, these two compounds also enhanced the expression of p53. p53 is a tumor suppressor playing numerous roles in inducing DNA repair, senescence, cell cycle arrest, and apoptosis. This result was consistent with those of previous studies investigating other series of xanthone. ${ }^{30,31}$ Noticeably, only compound $1 \mathrm{j}$ significantly up-regulated the expression of Bax protein. Bax, belonging to the Bcl-2 gene family, was central to the regulation of mitochondrial apoptosis. Collectively, these findings suggest that the high expression of apoptosis-related factors and p53 was the main mechanism of compound $1 \mathrm{j}$.

\section{Conclusion}

Most of the target compounds exerted a marked inhibitory effect on cancer cells. The activity of 18 compounds was higher than that of the intermediates 4 and 5. Moreover, the extensional structure of the 1,2,3-triazole ring and heterocycle groups was beneficial to anticancer activity. Compounds $1 \mathrm{~h}$ and $1 \mathrm{j}$ demonstrated the most potent inhibitory activity against A549 cells. The effects of compounds $1 \mathrm{~h}$ and $1 \mathrm{j}$ on early apoptosis, necrosis, and late apoptosis

\section{A}
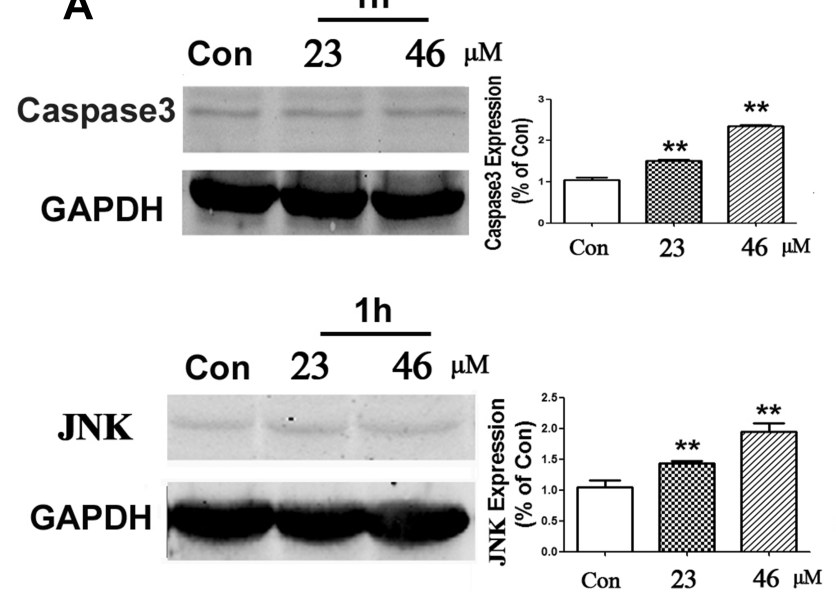

B
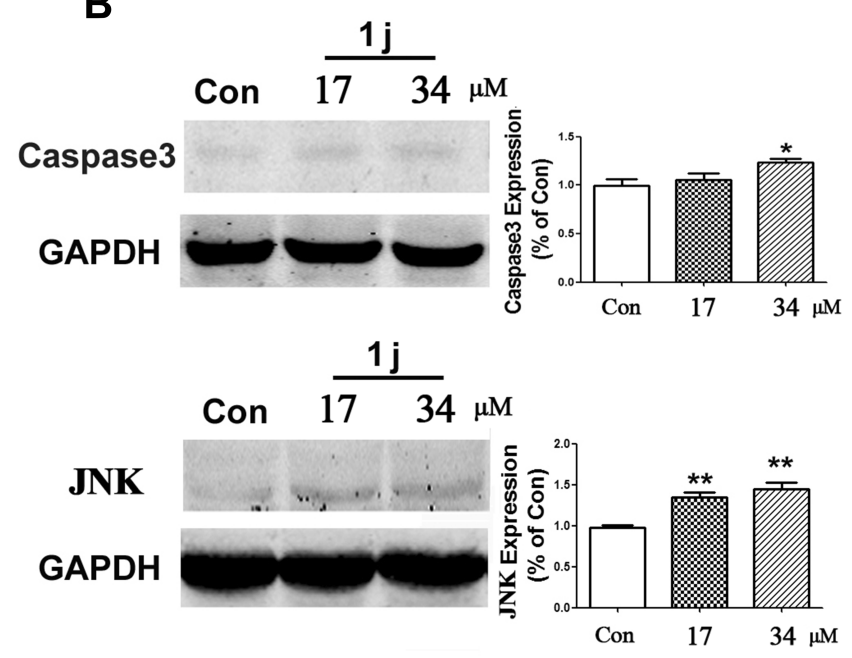
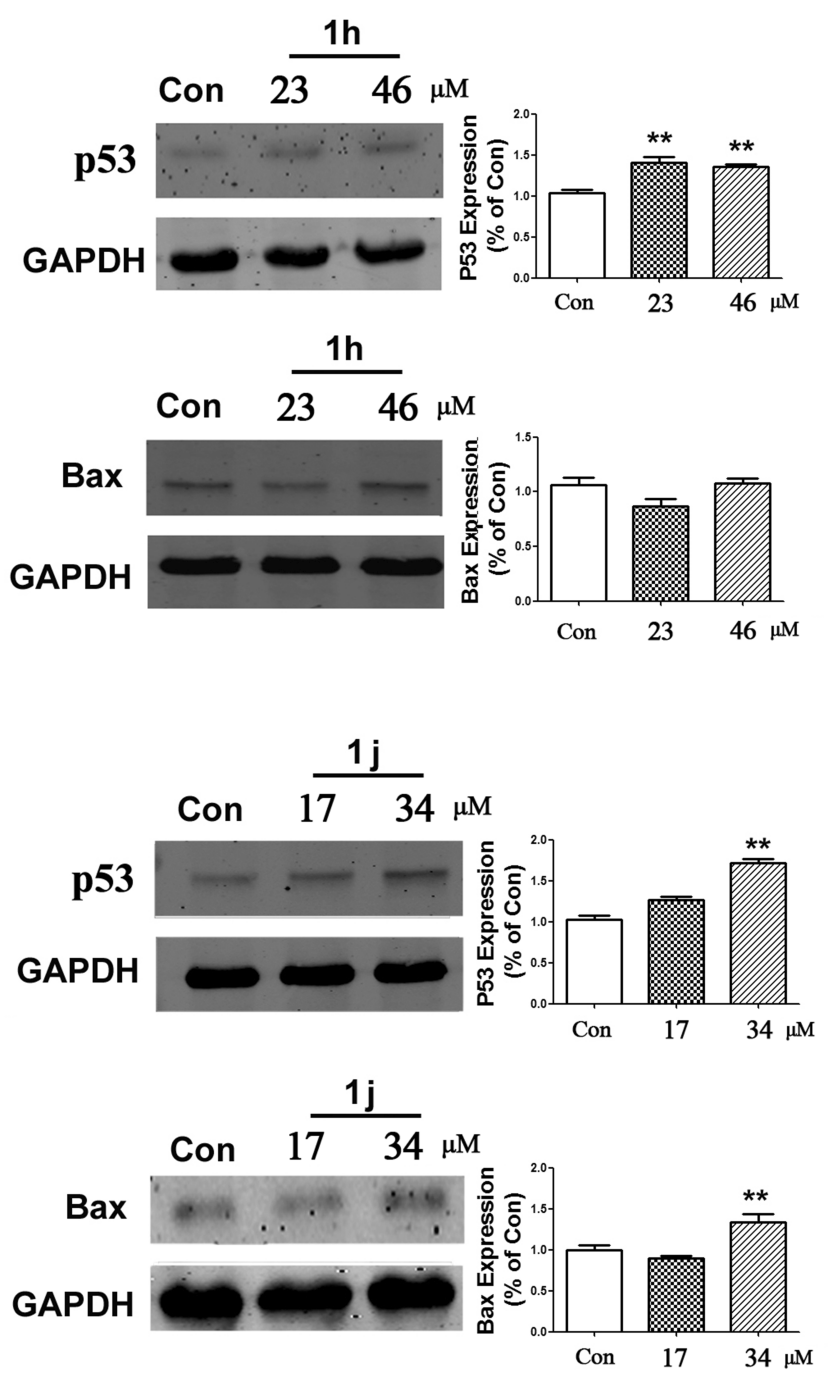

Figure 5 Effect of Ih (A) and Ij (B) on proteins related to cell death. A549 cells were treated with Ih (at a dose of 23 and $46 \mu \mathrm{M}$ ) and Ij (at a dose of I7 and $34 \mu \mathrm{M}$ ) for 12 hrs. The expression levels of proteins were measured using Western blotting. All data are presented as mean $\pm S E ; n=3$, ${ }^{p}<0.05$ vs Con; $* * p<0.01$ vs Con. 
were similar. The results of the Western blotting analysis indicated that compound $1 \mathrm{j}$ increased the expression of caspase 3, JNK, p53, and particularly Bax, providing a novel viewpoint of the effects of xanthone derivatives.

\section{Acknowledgments}

This work was supported by the National Natural Science Foundation of China (No. 21202200) and by the Project of Shanghai Science and Technology Transformation and Industrialization (15431908500).

\section{Disclosure}

The authors declare no conflict of interests in this work.

\section{References}

1. Molina JR, Yang P, Cassivi SD, Schild SE, Adjei AA. Non-small cell lung cancer: epidemiology, risk factors, treatment, and survivorship. Mayo Clin Proc. 2008;83(5):584-594.

2. Godugu C, Patel AR, Doddapaneni R, Marepally S, Jackson T, Singh M. Inhalation delivery of Telmisartan enhances intratumoral distribution of nanoparticles in lung cancer models. $J$ Control Release. 2013;172(1):86-95. doi:10.1016/j.jconrel.2013.06.036

3. Siegel RL, Miller KD, Jemal A. Cancer statistics, 2016. CA Cancer J Clin. 2016;66(1):7-30. doi:10.3322/caac.21332

4. Smith RA, Andrews KS, Brooks D, et al. Cancer screening in the United States, 2018: A review of current American Cancer Society guidelines and current issues in cancer screening. CA Cancer J Clin. 2018;68(4):297-316. doi:10.3322/caac.21446

5. Kumar CP, Reddy TS, Mainkar PS, et al. Synthesis and biological evaluation of 5, 10-dihydro-11H-dibenzo [b, e][1, 4] diazepin-11-one structural derivatives as anti-cancer and apoptosis inducing agents. Eur J Med Chem. 2016;108:674-686. doi:10.1016/j.ejmech.2015. 12.007

6. Rao PV, Nallappan D, Madhavi K, Rahman S, Jun Wei L, Gan SH. Phytochemicals and biogenic metallic nanoparticles as anticancer agents. Oxid Med Cell Longev. 2016;2016.

7. El-Seedi HR, El-Barbary MA, El-Ghorab DM, et al. Recent insights into the biosynthesis and biological activities of natural xanthones. Curr Med Chem. 2010;17(9):854-901. doi:10.2174/092986710790 712147

8. Tarushi A, Raptopoulou CP, Psycharis V, et al. Copper (II) Inverse[9-Metallacrown-3] compounds accommodating nitrato or diclofenac ligands: structure, magnetism, and biological activity. Eur J Inorg Chem. 2016;2016(2):219-231. doi:10.1002/ejic.201500769

9. Na Y. Recent cancer drug development with xanthone structures. J Pharm Pharmacol. 2009;61(6):707-712. doi:10.1211/jpp.61.06. 0002

10. Tarushi A, Psomas G, Raptopoulou CP, Kessissoglou DP. Zinc complexes of the antibacterial drug oxolinic acid: structure and DNA-binding properties. J Inorg Biochem. 2009;103(6):898-905. doi:10.1016/j.jinorgbio.2009.03.007

11. Wijeratne EM, Turbyville TJ, Fritz A, Whitesell L, Gunatilaka AA. A new dihydroxanthenone from a plant-associated strain of the fungus Chaetomium globosum demonstrates anticancer activity. Bioorg Med Chem. 2006;14(23):7917-7923. doi:10.1016/j.bmc.2006.07.048

12. Murata R, Horsman MR. Tumour-specific enhancement of thermoradiotherapy at mild temperatures by the vascular targeting agent 5,6-dimethylxanthenone-4-acetic acid. Int J Hyperther. 2004;20 (4):393-404. doi:10.1080/02656730310001619370
13. Shagufta AI. Recent insight into the biological activities of synthetic xanthone derivatives. Eur J Med Chem. 2016;116:267-280.

14. Castanheiro RA, Pinto MM, Silva AM, et al. Dihydroxyxanthones prenylated derivatives: synthesis, structure elucidation, and growth inhibitory activity on human tumor cell lines with improvement of selectivity for MCF-7. Bioorg Med Chem. 2007;15(18):6080-6088. doi:10.1016/j.bmc.2007.06.037

15. Wang X, Lu N, Yang Q, et al. Studies on chemical modification and biology of a natural product, gambogic acid (III): determination of the essential pharmacophore for biological activity. Eur J Med Chem. 2011;46(4):1280-1290. doi:10.1016/j.ejmech.2011.01.051

16. Zhang X, Li X, Sun H, et al. Garcinia xanthones as orally active antitumor agents. J Med Chem. 2013;56(1):276-292. doi:10.1021/ jm301593r

17. Dai M, Yuan X, Kang J, et al. Synthesis and biological evaluation of phenyl substituted polyoxygenated xanthone derivatives as anti-hepatoma agents. Eur J Med Chem. 2013;69:159-166. doi:10.1016/j.ejmech.2013.08.020

18. Yan SJ, Liu YJ, Chen YL, Liu L, Lin J. An efficient one-pot synthesis of heterocycle-fused 1,2,3-triazole derivatives as anti-cancer agents. Bioorg Med Chem Lett. 2010;20(17):5225-5228. doi:10.1016/j. bmcl.2010.06.141

19. Wang XL, Wan K, Zhou CH. Synthesis of novel sulfanilamide-derived 1,2,3-triazoles and their evaluation for antibacterial and antifungal activities. Eur J Med Chem. 2010;45 (10):4631-4639. doi:10.1016/j.ejmech.2010.07.031

20. Singh P, Sharma P, Anand A, et al. Azide-alkyne cycloaddition en route to novel $1 \mathrm{H}-1,2,3$-triazole tethered isatin conjugates with in vitro cytotoxic evaluation. Eur J Med Chem. 2012;55:455-461. doi:10.1016/j.ejmech.2012.06.057

21. He R, Chen Y, Chen Y, et al. Synthesis and biological evaluation of triazol-4-ylphenyl-bearing histone deacetylase inhibitors as anticancer agents. J Med Chem. 2010;53(3):1347-1356. doi:10.1021/ jm901667k

22. Kamal A, Prabhakar S, Janaki Ramaiah M, et al. Synthesis and anticancer activity of chalcone-pyrrolobenzodiazepine conjugates linked via 1,2,3-triazole ring side-armed with alkane spacers. Eur J Med Chem. 2011;46(9):3820-3831. doi:10.1016/j.ejmech.2011.05.050

23. Thomas KD, Adhikari AV, Chowdhury IH, Sumesh E, Pal NK. New quinolin-4-yl-1,2,3-triazoles carrying amides, sulphonamides and amidopiperazines as potential antitubercular agents. Eur J Med Chem. 2011;46(6):2503-2512. doi:10.1016/j.ejmech.2011.03.039

24. Wu J, Ni T, Chai X, et al. Molecular docking, design, synthesis and antifungal activity study of novel triazole derivatives. Eur J Med Chem. 2018;143:1840-1846.

25. Kamal A, Shankaraiah N, Devaiah V, et al. Synthesis of 1,2,3-triazole-linked pyrrolobenzodiazepine conjugates employing 'click' chemistry: DNA-binding affinity and anticancer activity. Bioorg Med Chem Lett. 2008;18(4):1468-1473. doi:10.1016/j.bmcl.2007. 12.063

26. Isobe H, Fujino T, Yamazaki N, Guillot-Nieckowski M, Nakamura E. Triazole-linked analogue of deoxyribonucleic acid ((TL)DNA): design, synthesis, and double-strand formation with natural DNA. Org Lett. 2008;10(17):3729-3732. doi:10.1021/o1801230k

27. Lee LV, Mitchell ML, Huang SJ, Fokin VV, Sharpless KB, Wong CH. $\mathrm{A}$ potent and highly selective inhibitor of human alpha-1,3-fucosyltransferase via click chemistry. $\mathrm{J} \mathrm{Am} \mathrm{Chem} \mathrm{Soc.}$ 2003;125(32):9588-9589. doi:10.1021/ja0302836

28. Qiu H-Y, Wang P-F, Li Z, et al. Synthesis of dihydropyrazole sulphonamide derivatives that act as anti-cancer agents through COX-2 inhibition. Pharmacol Res. 2016;104:86-96. doi:10.1016/j.phrs.2015. 12.025

29. Zhu Q, Zhang Y, Liu Y, et al. MLIF alleviates SH-SY5Y neuroblastoma injury induced by oxygen-glucose deprivation by targeting eukaryotic translation elongation factor 1A2. PLoS ONE. 2016;11 (2):e0149965. doi:10.1371/journal.pone.0149965 
30. Lauria A, Tutone M, Ippolito M, Pantano L, Almerico AM. Molecular modeling approaches in the discovery of new drugs for anti-cancer therapy: the investigation of p53-MDM2 interaction and its inhibition by small molecules. Curr Med Chem. 2010;17 (28):3142-3154. doi:10.2174/092986710792232021
31. Liu J, Zhang J, Wang H, et al. Synthesis of xanthone derivatives and studies on the inhibition against cancer cells growth and synergistic combinations of them. Eur J Med Chem. 2017;133:50-61. doi:10.1016/j.ejmech.2017.03.068

\section{Publish your work in this journal}

Drug Design, Development and Therapy is an international, peerreviewed open-access journal that spans the spectrum of drug design and development through to clinical applications. Clinical outcomes, patient safety, and programs for the development and effective, safe, and sustained use of medicines are a feature of the journal, which has also been accepted for indexing on PubMed Central. The manuscript management system is completely online and includes a very quick and fair peer-review system, which is all easy to use. Visit http://www. dovepress.com/testimonials.php to read real quotes from published authors. 